Utasi Csilla*

УДК 821.511.141-14.09 Zrínyi M.

Bölcsészettudományi Kar

DOI: $10.19090 /$ gff.2017.1.171-181

Újvidéki Egyetem

Originalni naučni rad

\title{
KÉPELMÉLETI KÉRDÉSEK ZRÍNYI MIKLÓS SYRENA-KÖTETÉBEN
}

Giambattisto Marino festményeket leíró verseiben az ut pictura poesis-elmélet kérdéseire játszik rá. Zrínyi, aki pedig a Syrena-kötetben sokszor imitálja Marinót, a képelmélet vonatkozásában nem követi őt. Zrínyinek ennek ellenére egyik legjelentősebb költői eszköze a jelenségeket különös erővel megjelenítő kép, melyet a retorikai hagyomány enargeiának vagy evidentiának nevez. A dolgozat szerzője szerint a képelmélet a Syrena-kötetben a díszcímlap megformálásán hagy nyomot. A metszet valószínüleg az Obsidio XIV. énekének kezdő reflexióját ábrázolja. Ha a címlapkép tengeri jelenete valóban a szövegben az eposzírást jelölö metaforát, a hajózást ábrázolja a vizuális kép eszközeivel, akkor joggal tételezhetjük fel, hogy a kép allegorikus alakjai közül a magát tükörben fésülő szirén a kötet költői diskurzusát jeleníti meg. A Syrena-kötetnek azt költői diskurzusát, amely Marino képelméletével sok rokon vonást mutat.

Kulcsszavak: Zrínyi Miklós, Syrena-kötet, enargeia, ut pictura poesis, Giambattista Marino, képelmélet, petrarkizmus, superatio

\section{AZ ÖNREPREZENTÁCIÓ ZRÍNYI MIKLÓS SYRENA-KÖTETÉBEN}

A Syrena-kötet címével Zrínyi Miklós Giambattista Marino lírájának adózik. Az olasz költő müvészetét barátai és müvének értői már első kötete, a Rime (1602) megjelenését követően az itáliai félszigetet megtermékenyítő tengerhez hasonlították. Versei háromkötetes kiadásában, melyet Marino 1614-ben La Lira címen publikált - Zrínyi könyvtárában ez a gyüjtemény a következő, 1615-1616-os kiadásban volt meg (Hausner \& at al, 1991: 291-292) -, Marino egy tucat hozzáírt panegyricust is közzétett, amelyek mind a Marino-mare és a Sirena-motívumot variálják (Pfisterer, 2013: 443). A La Sampogna elején közölt költői levelek közül a harmadikban, melynek Claudio Achillini a címzettje, Marino a szirén fiacskájának nevezi önmagát (Marino, 1621:25).

Marino festményeket leíró verseiben az ut pictura poesis-elmélet kérdéseire játszik rá. Zrínyi a képelmélet vonatkozásában nem imitálja Marinót, a Syrenakötetben azonban az önreprezentáció egyik legjelentősebb költői eszköze a jelenségeket különös erővel megjelenítő kép.

*csilla.utasi@ff.uns.ac.rs 
A nyelv „képszerüségét”, „képalkotó képességét” már a görög hagyományban az enargeia fogalmával írták le. A fogalom egyaránt jelölte a költőnek és szónoknak azt az eljárását, mellyel az elbeszélt tárgyakat és tetteket képszerủen a befogadó szeme elé tárják, és magának a nyelvnek a képalkotó tevékenységét. Quintilianus meghatározásában: „az enargeia, amit Cicero illustratiónak és evidentiának nevez, (...) nem annyira elmondani látszik a dolgokat, mint megmutatni, és olyan érzelmeket ébreszt, mintha személyesen jelen lennénk (Quintilianus, 2009: 6, 2, 33, 416-417). A megalakuló reneszánsz költészetelméletben alapvető szerepet kapó enargeia-fogalom elméletét az eposz megújulásának, a Poétika intenzív értelmezésének időszakában, a 16. században dolgozták ki.

\section{A DÍSZCÍMLAP MINT ÖSSZEGZÖ KÉP}

A Syrena-kötethez Zrínyi Miklós összegző szerepü díszcímlapot készíttetett.

A díszcímlap készítője, Juraj Šubarić 1644 és 1652 között, abban az időszakban, melyben bécsi tevékenységét nyomon követhetjük, Matthäus Cosmeroviusszal és Matthäus Rickhesszel müködött együtt. Alkalmi röplapokat, allegorikus címlapképeket, kegyességi képeket, portrékat, ex libriseket készített megrendelöi, a Királyi Magyarország főnemesei számára (Pelc, 2015). A díszcímlapot megrendelő Zrínyi Miklós mintha megfordítaná Marino kötetének, a La Galeriának alapeljárását: ahelyett, hogy a nyelv médiumában festményeket írna le, a Syrena-kötetet, az eposz elbeszélését a kép médiumának segítségével jeleníti meg.

A díszcímlap valószínüleg az eposz egyik különleges, az elbeszélés metasíkját fölvillantó concettójára, a XIV. ének kezdő reflexiójára utal:

Ihon jün Zrininek ragyagó csillaga,

Ihon mozdulhatatlan tramontanája,

Bán cselekedetét az én kezem írja,

Mellyet Isten lölke elmémben befúja.

Nem távozik annak veszélyre hajója,

Melynek ez csillaghoz tart okos kormánya,

Hủvség, vitézség ennek calamitája,

Az mely ez csillagot veszteni nem hagyja. (Szv XIV. 1-3)

Az eposzírás vállalkozását az antik szerzők mintájára Zrínyi is a tengeren való átkelés metaforájával jelöli. Az ének kezdősorában (,Ihon jün a Zrini ragyagó csillaga") az éjszakai égen feltünik a Zrínyi-nemzetség csillaga: a szigeti várvédő mártírhalálának metaforája. A metatájék egén a metafora csillagként, valóságos 
látványként jelenik meg. Az elbeszélő alakján ugyanakkor áttűnik az életét a példához igazító szerző alakja is: hajózás képe a belső tulajdonságokat, erényeket feltételezö tettet is megjeleníti.

A metszeten látható páncélba öltözött vitéz merően elöre néz. A csillag, amelyre a tekintetét valószínűleg veti, kívül van a képen rögzített valóságon. Abban az önreflexív, fiktív pillanatban, melyet a kép megragad, a szirének, a tenger lakói veszik körül a hajót. A bárkába kapaszkodó jobb oldali szirén kagylót nyújt a páncélba öltözött kormányosnak. A kagyló a szexuális aktus, az erotikus költészet jelképe. A bárka oldalánál lebegő, fésülködő sellő tükröt tart maga elé, kissé a kép szemlélője felé fordítva a tükör felületét, melyen arca reflektálódik. A Syrenakötetből kiragadott szöveghelyek, például a Feszületre kezdőképe, a „rothadandó fü” megengedik a tükör vanitas-szimbólumként való felfogását is.

Ha a kép fö figurájának az olvasó számára is példaértékü megtérése állna a Syrena-kötet középpontjában, a címlapmetszet valószínűleg a szakrális reprezentáció teljes szerkezetével rendelkezne: a kép jobb felső sarkában a szigeti várvédő térdelne dicsfénytôl övezetten, fején a mártírok koronájával.

Az embléma picturájának elemei térben helyezkednek el, a látványt gyakran semmi sem különbözteti meg a matematikai perspektíva szabályai szerint megalkotott képtől, máskor a heterogén részletek térbeli kapcsolata eleve jelzi a képtől való eltérést. Az inscriptio és az epigramma úgy társítanak a képen ábrázolt tárgyak együtteséhez topikus tudást, hogy elemeire bontják a látványt és az izolált képi elemei között értelmi összefüggést teremtenek. Az embléma általánosan érvényes tudást jelenít meg: a könyvek címlapján a kötet jelentését vagy a szerző szándékát gyakran több embléma együttese érzékelteti. (Peil, 2008: 309-311).

A Syrena-kötet címlapján ábrázolt tengeri táj nem szakrális reprezentációként vagy emblémaként, hanem képként jeleníti meg a szerzőt és müvét. Šubarić metszete talán azért áll szívósan ellent az értelmezői kísérleteknek, mert a megrendelő, Zrínyi intenciója a kép allegorikus figurái közötti viszonyt nem jelölte ki világosan.

\section{A SYRENA-KÖTET EVIDENCIÁI}

A Syrena-kötet a paratextusok után a két Idiliummal kezdődik, majd az Obsidió- $t$ újabb erotikus versek, az Epigrammata, a Feszületre címü himnusz és végül a Peroratio követik.

A petrarkista költészet szubjektuma a szerelmi érzés állapotát jelölö toposzok segítségével formálja meg önmagát (Wesche, 2010: 59-63). Az olasz és spanyol barokk erotikus költészet is, a német is, melyben jelentős petrarkizmus 
korábban nem alakult ki, a petrarkizmus alappozícióit vonja kétségbe, értelmezi át. Zrínyi a superatio eljárását alkalmazza, lírai énje a petrarkista költészet beszédhelyzetét úgy múlja felül, hogy a lírai én saját szenvedélyét végtelennek, parttalannak állítja.

Az Arianna sírásának kezdőképeiben a petrarkista hasonlatok állításait olyan kérdésekké formálja, melyekben a petrarkista versek állításaihoz képest helyet cserél a hasonló és a hasonlított:

Adria tengernek fönn forgó habjai

Vajon oly nagyok-é, mint szemeim árjai,

Vajon oly nagyok-é, mint Mongyibél lángjai?

Mint szüvemnek lángos hatalmai (Arianna sírása, 1) ${ }^{1}$.

A superatio gesztusa a versek egyes szám első személyben beszélő szerelmesének a dignitas minőségét kölcsönzi. Zrínyi a képhatárok jelölésére a régiségnek nem csak magyar költészetre jellemző eszközét, az aposztrophét használja. A múlt és a jelen idő váltogatása hasonlóképpen a képek kezdetét és végét jelöli ki költeményeiben. A monológok (arietták, canzonetták) vagy párbeszédek nem a lírai én szerelmi kazuisztikájának a részei, hanem ezek is önálló, képszerü kivágatban jelennek meg.

Az Olvasónak szóló ajánlás, noha a Syrena-kötet legelején helyezkedik el, már az elkészült müre tekint vissza, a szerelmi költészet igazolása is utólagos érvényü tehát. A „csendesen” való írás talán a burkolt, fátyolozott kifejezésmódot jelenti, nem pedig a kötetben található erotikus költészet szelídségét vagy szemérmességét. A fátyolozott kifejezésmódnak Zrínyi rögtön példáját is adja: Petronius Arbiternek a Mars sisakjában fészket rakó galambokról szóló epigrammája Mars és Venus házasságtörő szerelmével igazolja az erotikus költészet létjogosulságát. Orpheuszhoz, a mitológiai szereplőhöz a kora újkori kultúrában a mértéktelen szerelem képzete társult. A történetét feldolgozó múvek a baljós kimenetelt általános morális tanulságul állították a befogadó elé. Zrínyi, amikor Orpheusz álarcában saját gyászáról vallott, nem függetlenedhetett teljes mértékben a keresztény antropológia tanításától. Az Eurüdice halálát leíró versszakban a halál ugyanúgy a transzcendencia hatalmában áll, mint ahogyan a keresztény elképzelés szerint:

Euridice oly volt, mint egy szép virágszál,

Mint a legszebbik csillag, mely sokak között áll,

\footnotetext{
${ }^{1}$ A Syrena-kötetre a hasonmás kiadás (Zrínyi 1981) alapján hivatkozom. A kötet ívjelzése nem következetes, az idézetek esetében ezért a címet és a versszakot adom meg. Az Obsidio Szigethiana cím rövidítése: Szv. Zrínyi Miklós szövegét saját átiratomban közlöm.
} 
Ezt elvitte az irigy s kegyetlen halál,

És ezért nyugodalmat szüvem nem talál (Orpheusz I., 3).

A Syrena-kötetben a szerelem (és közvetve az erotikus költészet is) nem morális szempontból, hanem a halálról is döntő Isten hatalmához képest bizonyul elégtelennek. Az Orpheusz-versektől kezdve a szerelmes evidentiaszerüen megjelenített állapota egy nagyobb, átfogóbb viszonyhoz mérődik hozzá.

A Feszületre a kötet szemléleti középpontja. A kor meditatív lírájában a beszélő általában saját lelkét szólítja fel bünbánatra. Zrínyi mintájában, Girolamo Preti, Invita l'anima sua a piagnere la morte di Cristo címü versének címe szerint (Preti, 2003) saját lelkét utasítja töredelemre². Zrínyi a lélek szerepét az édes Múzsára, az erotikus líra énjét megtestesítő allegorikus alakra ruházza át.

A Feszületre beszélője a Múzsát így inti: „Sírtál már eleget Ariannáért” (Feszületre, 1) azaz Arianna nevében, az ő szerepében. A Múzsa alakja azonban egyúttal az erotikus költészet diskurzusának megtestesítője is: azért kell bünbánatot gyakorolnia, mert az erotikus költészet dicsősége „rothadandó fü” (Feszületre, 1). Kérdésként merül föl, hogy a megfeszített Krisztus sorsának átérzése, a compassio tisztán affektus marad-e, vagy az erotikus költészethez hasonlóan kívülröl szemlélhető képként is megszerveződik.

A megfeszített Krisztus képmása előtt álló versbeni beszélő, a megfeszítés bünéből részt vállalva, a következő kérdést intézi Istenhez: „Hogy nézhetsz emberre, ember teremtője?” (Feszületre, 3) A vitézek Istenét szólítja meg: a kétértelmü birtokos szerkezet egyszerre jelenti a vitézkedőkre gondot viselö Istent és az athleta Christi képzetét, mely a megtestesülés következményének meghökkentő értelmezését adja az alábbi verssorban: „Bajt víttál, harcoltál halállal vitézül” (Feszületre, 5). A versén Istenhez többesszám egyesben fordul. A költemény utolsó harmadát elfoglaló argumentáció számos más vershez hasonlóan a bünök elengedését Isten irgalmára hivatkozva kéri. A himnusz végén a compassióról vagy az Isten és a magát bünösnek tartó beszélő szövetségét helyreállító érvelésről Isten kegyelmére helyeződik át a hangsúly. A beszélő a versben előbb a teremtőként, majd metaforikusan Krisztusként, végül sokféle ószövetségi nevén szólítja meg a megfoghatatlan Istent: a himnusz mindenekelött azt az asszimetrikus viszonyt képezi meg, amelyben Istennek az emberre vetett tekintete megelőzi a pillantást viszonozni nem tudó ember tekintetét. Isten színe

\footnotetext{
${ }^{2}$ Az olasz költemény is aposztrophéval kezdődik: a versbeni beszélő fájó szemét szólítja fel, hogy ezután méltóért sírjon, önmaga meggyőzésére szánt érveit azonban, például azt, hogy a szép szempárt, melyért azelőtt hullatta könnyeit, Isten teremtette, egyes szám első személyben, kijelentő módban adja elő (Preti, 2003).
} 
látása nem adatik meg a földi életben (a visio beatificá-ról lásd Kőszeghy, 2014: 324-325) Angelus Silesius a Cherubinischer Wandersmann címü munkáját Isten örök bölcsességének, a makula nélküli tükörnek ajánlja, melybe a cherubok és a boldog lelkek tekintenek; az örök fénynek, mely minden embert megvilágít. A költemény záradékában a szerző az Ő látására való vágyakozástól minden percben meghalóként jellemzi önmagát (Idézi Moennighoff, 2008: 346-347).

A Metamorphoses záró sorait parafrazáló Peroratio versénje büszkén állítja, véghezvitte immár munkáját. Kijelenti, hogy amikor eljön az a nap, mely testén uralkodhatik csak: „Hatalma magamnak, ugyan nagyobb részem / Hordoztatik széllel az magas egeken” (Peroratio, 2). A „nagyobb rész” égbeli megnyilvánulására a Scitiából kijövő magyarok útvonalán mindenütt tekintetek sokasága szegeződik. Míg e kép esetében az olvasó a tömeges rátekintés jelenetét látja maga előtt, a zárókép esetében az olvasónak azt a tettet kell maga elé képzelnie, mely a müben leírt cselekedetet megismétli. A haza hamuja, mellyel a lírai én beboríttatik, a szigeti várvédéshez hasonló vesztes szituációt jelöl. A betemetés képzetéhez szorosan hozzátartozik a vakságé. A halál előtti pillanatot és a szemtől szemben való látás lehetetlenségét leíró kép metaforikusan az üdvösség bizonyosságát fejezi ki.

A Peroratióban megidézett mindkét látvány enargeia vagy evidentia abban az értelemben, hogy a história folyását, az emberi törekvést: a fama keresését és az örök dolgokat egyetlen képbe foglalja.

A koronájaként csillagokat viselő Szüz Máriától az eposz elbeszélője azt kéri invocatiójában: „úgy írhassak, mint volt” ( $S z v$ I., 5). A kérés a hü ábrázolás a történeti tényszerüségen túl a szigetvári hős tettének azokat a szemléleti, morális, érzelmi és hitbeli indítékait is felöleli, amelyek a szigeti hős halálát Zrínyi számára a követhető magatartás kizárólagos mintájává teszik.

A kisebb költeményeknek a kötet szerkezetében az a szerepük, hogy az eposznak mint sorsmintának a szemléleti elemeit és azok egymáshoz való viszonyát kifejezzék.

\section{GIAMBATTISTA MARINO KÉPELMÉLETE}

Nem tudjuk, Zrínyi Miklós ismerhette-e Giambattista Marino többszáz oldalas, 1614-ben Dicerie sacre címen publikált prózamüvét, melynek első könyve a festészetről, a második a zenéről, a harmadik pedig az Égről szól. Értekezésében a képzőmüvészeti kép kérdéseit evidentiák sokaságával érzékelteti, az értekezés képeket görgető szövegét pedig tükörkabinetthez hasonlítja. A tükör a szemtől szemben való látás lehetetlenségére utal. Marino szerint a képi reprezentáció két 
tekintetben is tükröződés. Minden kép egy látvány tükörképe - reflexe -, ugyanakkor az emberi megismerés - reflexió - eredménye is. Marino a teremtés valamennyi látványát képnek fogja fel, és megállapítja, Isten voltaképpen festő. (Flemming, 2013: 18-29).

Marino a festészetet az ókor óta övező gyanú álláspontjára helyezkedik, amikor kijelenti, Isten festőként való müködése nem komoly tevékenység: a teremtés játék, Isten ujjgyakorlata. Marino szerint azonban Isten megteremti valódi, titkos képmását is, a „láthatatlan kép”-et: az Igét. Az Ige Krisztus alakjában vált láthatóvá, életének egy-egy pillanatában föllebbent a fátyol ${ }^{3}$ (Flemming, 2013: 3436). A nézőnek minden festményen a nem láthatót, a képpé nem változtatható transzcendenciát kell keresnie. A kép létmódja látszat, ám éppen a látszat nyílt vállalásával képes a kép az igazság megjelenítésére. Marino nem tesz különbséget a képzőművészeti és a nyelvi, a valóságos és a fantáziakép között, felfogásában tehát a költői beszédet ugyanúgy az ismeretelméleti kétesség és az igazság megjelenítésének kettőssége jellemzi.

A Dicerie sacre hatalmas antik müveltséganyagot mozgósít, a képelmélet újdonságának megértéséhez nem képzőmüvészeti tájékozottságra, hanem elsősorban müveltségre volt szükség. Zrínyi Miklós a gyakorlatból is ismerhette Marino képelméleti nézeteit. Az olasz szerző La Galeria ${ }^{4}$ című, a Dicerie sacre törekvéseit bizonyos értelemben folytató gyüjteménye szerepel a Bibliotheca Zriniana katalógusában ${ }^{5}$.

${ }^{3}$ Marino az értekezés megjelenésének idején a torinói udvar szolgálatában állt, egyik nyilvános megmutatásakor látta a torinói halotti leplet, amelyet utóbb értekezésének rejtett vonatkozási pontjává tett. Marino a Santa Sindoné-t „semmi”-nek nevezi. (Fleming, 2013: 36). Joggal nevezhette semminek, hiszen az arc és a test a 19. században a lepelröl készített fotó üvegnegatívján mutatkozott meg elöször. A hiteles képmás kérdéséről magyarul lásd Belting, 2005; a torinói lepel fényképfelvételéröl Belting, 2005: 89-95.

${ }^{4}$ Marino 1605 táján, a gyüjtemény ötletének megszületésekor még csak egy Varro és Paolo Giovio portrégalériáihoz hasonló kötetet tervezett. 1610/11 táján előbb „favolákkal” (favole) majd szobrok leírásával egészítette ki a gyüjteményt. Legközelebbi mintája valószínűleg a padovai Accademia degli Orditi kiadásában 1611-ben megjelent, Itália legjobb költőit összegyüjtő antológia, a Careggiamento poetico volt. Ennek Le Immagini címet viselö, a kötet egyharmadát kitevő fejezete több szerző, kizárólag festményeket leíró költeményeit tartalmazza. Marino a La Galeriába csupán saját verseit sorolta be, saját ingegnó-ját versenyezteti. (Pfisterer, 2013: 435-436).

${ }^{5}$ Marino kötetének kezdetén, azon a helyen, ahol szabályszerủen az arcképét vagy egy jelentős mitológiai eseményt megörökítő kép leírásának kellene állnia, Marino két Venust ábrázoló festmény leírását helyezte el (Marino, 1664 [1620]: 5-6). Az első költemény 
Hogy Zrínyi a díszcímlapon ábrázolt allegorikus alakok egymáshoz való viszonyát homályban hagyta, az az ut pictura poesis-vitában való állástfoglalását jelenti.

A magát tükörben néző, a tükör felszínét kirajzolódó arca reflexével kissé a néző felé fordító szirén a tükörképnek talán azt a szimbolikus jelentését idézi meg, melyet a festészet kora újkori elméletei, például Leon Battista Alberti De pictura címü traktátusa tulajdonítanak neki ${ }^{6}$. A tükröt tartó szirén a költői (és a képzőmüvészeti) képet jelentheti, amely mindenkor illúzión alapul, ám az illúzió segítségével az igazságot jeleníti meg. Ha így van, akkor Zrínyi Miklósnak a költői nyelvről való felfogása - a kettejük között tátongó világnézeti különbség ellenére közelebb áll Marino képelméletéhez, mint ahogyan eddig sejtettük.

\section{Utasi Csilla}

\section{QUESTIONS OF PICTURE THEORY IN MIKLÓS ZRÍNYI'S SIREN VOLUME}

\section{Summary}

In the era of baroque literature, poets were often compared to heroes of Greek and Roman mythology, as well as to the sirens, among others. Miklós Zrínyi followed this tradition by calling himself a siren in his volume entitled The Siren of the Adriatic Sea: Count Miklós Zrinyi. Zrínyi owes this gesture to the poetry of Giambattista Marino, who was referred to as the siren of the Tyrrhenian Sea by his contemporaries. In addition to the several of Marino volumes, La Galleria could be also found in Zrínyi's abundant library. In La Galleria,

mintája Jacopo Palma il Giovane Venus leveti ruháit Mars elött címủ vászna. Az egyébként is mindig meztelenül ábrázolt, itt az ágyon heverő szerelemistennő fegyverei letételére kényszeríti Marsot. A vers felütésében a lírai én Venust felszólítja, bájait takarja el, hiszen a vágyat a lefátyolozott szépség növeli. A vers záradéka a festő pálmaágat, illetve kézfejet jelentő nevére játszik rá. Amint Marino írja, Palma kezével a szerelemistennő meztelenségét nem befedi, hanem teste titkos szépségét felfedi. A költeményben Marino rejtetten állást foglal a festészet és a költészet elsőbbségéről folytatott vitában, a dolgokat nyíltan megmutató festészettel szemben az imaginatiónak teret engedő költészetnek juttatja az elsőbbséget. (Pfisterer, 2013: 440). A második költemény Bernardo Castello mára elveszett festményét jeleníti meg. A versben azt állítja, a kagylójában kuporgó Vénus a tengerben szebb, mint az égen: „Az ég és a tenger hangsúlyos szembeállítása - in mar - azonban egyféle, a MARinóra vonatkozó »argumentum a nominé«-t sejtet, a költő rejtett aláírását" (Pfisterer, 2013: 443).

${ }^{6}$ Alberti munkája második könyvében azt állítja, a poéták úgy tudják, a festészet feltalálója az utóbb virággá változtatott Nárcisszosz volt: „Mi mást jelent a festés, mint a mủvészettel a patak felszínét átölelni?” (Alberti, 2013 :46). 
Marino's descriptions of the canvases of contemporary painters suggest that poetry is more valuable than painting. Zrínyi imitates Marino's epic and lyrical works in his numerous collections. The frontispiece of the Siren volume illustrates the introductory reflection of the epic's $14^{\text {th }}$ poem, in which the flow of the narrative is denoted by sailing metaphors. Here, Miklós Zrínyi depicts himself as an armoured knight. The knight is the captain of the ship: he stares outward, his eyes focused on a point next to the image. Two sirens swim beside his ship. One holds onto the edge of the boat and hands a shell to its captain as a symbol of sensual union and sexuality. The other siren combs her hair while gazing at herself in a mirror. This paper argues that the allegorical images on the frontispiece do not depict sins and virtues. Rather, the knight in the picture represents heroic poetry, the mermaid holding a shell represents the volume's erotic poems, and the siren gazing at herself in the mirror represents the entire volume's poetic discourse. By arranging the frontispiece in this manner, it is as if Miklós Zrínyi is reversing Marino's gesture: He does not describe paintings through the medium of poetry as Marino does, but instead displays the whole meaning of the volume through the medium of an image on the frontispiece of his collection.

Keywords: Miklós Zrínyi, Siren volume, enargeia, Nikola Zrinski, ut pictura poesis, Giambattista Marino, picture theory, Petrarchism, superatio

\section{Čila Utaši}

\section{PITANJA TEORIJE O SLICI U ZBIRCI SIRENA NIKOLE ZRINSKOG}

\section{Sažetak}

Naslov zbirke Adriai tengernek Syreneaia (Jadranskoga mora Sirena), objavljene 1651. godine, može se tumačiti kao svojevrstan omaž Đanbatisti Marinu (Giambattista Marino). Nikola Zrinski, autor pomenute zbirke, bio je inspirisan poezijom ovog italijanskog pesnika. U delima Marina ut pictura poesis teorija igra važnu ulogu, a u svom traktatu pod naslovom Dicerie sacre iz 1614. godine autor je razvio i jednu posebnu teoriju slike. Iz književnog opusa Nikole Zrinskog se ne može zaključiti da li je on poznavao Marinovu teoriju slike. U svojoj biblioteci imao je samo zbirku pod naslovom La Galeria. U pesmama zbirke Sirena nema tragova teorije ut pictura poesis. Ipak, Nikola Zrinski, uređujući naslovnicu svoje zbirke, kao da obrće imitacijski gest Marina u njegovu suprotnost. U svojim pesmama Zrinski ne opisuje platna poznatih slikara, kao što to Marino čini, već značenje zbirke predstavlja pomoću medija slike. Naslovnica zbirke aludira na početnu refleksiju XIV pevanja epa: na ovom mestu teksta čin pripovedanja je opisan metaforama plovidbe. U saglasju sa tekstualnom metaforom plovidbe na naslovnici autor je prikazan kako upravlja brodom nalik na školjku. Obučen u pancir, on gleda pravo ispred sebe, pogled mu je uprt u jednu tačku koja se nalazi izvan slike. Kraj njegovog broda lebde dve sirene, jedna se pridržava za pramac barke i nudi kormilaru broda školjku: simbol polnog akta i seksualnosti. Druga sirena češlja svoju kosu, dok se gleda u ogledalu. Možemo zaključiti da alegorijske figure gravure ne predstavljaju grehove i vrline. Naime, vitez na slici označava herojsku književnost, sirena sa školjkom erotske pesme zbirke, dok je lik sirene sa ogledalom alegorija celokupnog poetskog diskursa zbirke.

Ključne reči: Nikola Zrinski, zbirka Sirena, enargeja, ut pictura poesis, Đanbatista Marino (Giambattista Marino), teorija slike, petrarkizam, superacija 


\section{FORRÁSOK}

Hausner, G., Klaniczay, T., Kovács S. I., Monok, I., Orlovszky G. (1991). A Bibliotheka Zriniana története és állománya. Budapest: Argumentum Kiadó-Zrínyi Kiadó.

Marino, G. B. (1664 [1620]). La Galeria del cavalier Marino. Distinta in pitture, \& sculture.

Venetia: Presso G.P. Brigonci. https://archive.org/details/lagaleriadelcav00 marigoog (letöltve: 2017. május 20.)

Marino, G. B. (1621). La sampogna del caualier Marino, diuisa in idillij fauolosi, \& pastorali. Venetia: apresso i Giunti. http://books.google.com/books?id= 0AVi0vgj7VYC\&hl=\&source=gbs_api (letöltve: 2017. március 27.)

Preti, G. 2003. Invita l'anima sua a piagnere la morte di Cristo In Poesie. Biblioteca Italiana. http://ww2.bibliotecaitaliana.it/xtf/view?docId= bibit000364/bibit000364.xml\&chunk.id=d3871e6346\&toc.depth=1\&toc.id $=\&$ brand=bibit (letöltve: 2017. július 7.)

Zrínyi, M. Zrínyi, (1980). Adriai tengernek Syreneaia (1651). Kovács Sándor Iván (utószó). Bécs: Cosmerovius. Hasonmás kiadás.

\section{IRODALOM}

Alberti, L. B. (2013). On picture. Ed. and transl.by Sinisgalli, R. Cambridge, New York, Melbourne, Madrid, Cape Town, Singapore, São Paulo, Delhi, Mexico City: Cambridge University Press.

Belting, H. (2005). A hiteles kép: Képviták mint hitviták. Ford. Hidas, Z. Budapest: Atlantisz.

Flemming, V. von (2013). Was ist ein Bild?:Marinos Dicerie sacre. Stillers, R. und Kruse, Ch. (hrsg.) (2013). In: Barocke Bildkulturen: Dialog der Künste in Giovan Battista Marinos „Galeria”. Wiesbaden: Harrasowitz Verlag (Wolfenbütteler Arbeiten zur Barockforschung, 48). 15-43.

Kőszeghy, P. (2014). Balassi Bálint. Magyar Amphión. Budapest: Balassi Kiadó. Moenninghoff, B. (2008). Die Kunst des literarischen Schenkens: Über einige Widmungsregeln im barocken Buch. Von Ammon, F. und Vögel, H. (hrsg.) (2008). Die Pluralisierung des Paratexts in der Frühen Neuzeit: Theorie, Formen, Funktionen. Berlin-Münster-Wien-Zürich-London: LIT Verlag (Pluralisierung \& Autorität). 337-352.

Peil, D. (2008). Titelkupfer/ Titelblatt- ein Programm?: Beobachtungen zur Funktion von Titelkupfer und Titelblatt in ausgewählten Beispielen aus dem 
17. Jahrhundert. Von Ammon, F. und Vögel , H. (hrsg.) (2008). Die Pluralisierung des Paratexts in der Frühen Neuzeit: Theorie, Formen, Funktionen. Berlin-Münster-Wien-Zürich-London: LIT Verlag (Pluralisierung \& Autorität). 301-336.

Pelc, M. (2015). „Georgius Subarich sculpsit Viennae - bakrorezac Juraj Šubarić u Beču oko 1650. godine: Djela i naručitelji”. Radovi Instituta za povijest umjetnosti, 39, 55-74.

Pfisterer, U. (2013). Iconologia Mariana: Marinos Selbst- und Fremdbilder. Stillers, R. und Kruse, Ch. (hrsg.) (2013). Barocke Bildkulturen: Dialog der Künste in Giovan Battista Marinos „Galeria”. Wiesbaden: Harrasowitz Verlag (Wolfenbütteler Arbeiten zur Barockforschung, 48). 433-469.

Quintilianus, M. F. (2009). Szónoklattan. Ford. Adamik, T., Csehy, Z., Gonda, A., Kopeczky, R., Krupp, J., Polgár, A., Simon, L. Z., Tordai, É. Budapest: Pesti Kalligram.

Wesche, J. (2010). Petrarkismus. Herbert Jaumann, H. (hrsg.) (2010). Diskurse der Gelehrtenkultur in der Frühen Neuzeit: Ein Handbuch. Berlin: De Gruyter. 55-84. 